\title{
SISTEM PELAYANAN PENDIDIKAN TERHADAP ANAK PENYANDANG DISABILITAS \\ (Studi Kasus di Sekolah Khusus Negeri 1 Kendari)
}

Rizky Novri Damayanti ${ }^{1}$, Sulsalman Moita ${ }^{2}$, Aryuni Salpiana Jabar ${ }^{3}$

${ }^{123}$ Fakultas Ilmu Sosial dan Ilmu Politik Universitas Halu Oleo

E-mail: Rizky_novry@yahoo.co.id, Moitasulsalman@yahoo.co.id, Aryunijabar@gmail.com

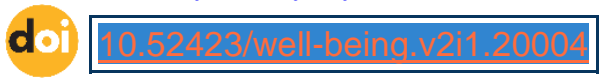

\section{ABSTRACT}

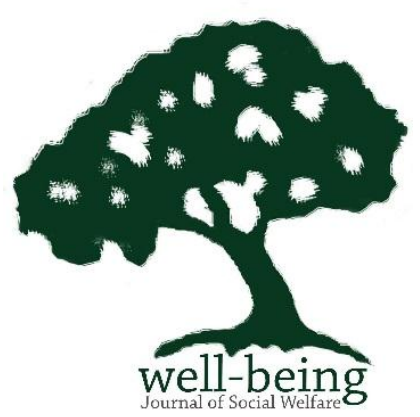

The purpose of this study was to examine educational services for children at the Kendari 1 State Special School and to determine the factors supporting and inhibiting educational services for children at the Kendari 1 State Special School. This research uses descriptive qualitative research with data techniques, interviews, and documentation. The results of the study indicate that services for children with disabilities are certainly different from other general children or must be in accordance with the needs of these children where in providing lessons or providing facilities so that they must have a special strategy or program. Supporting factors for children with disabilities in Kendari 1 State Special School are the government, family, teachers and the environment. Meanwhile, the inhibiting factors for children with disabilities in Kendari 1 State Special School are lack of teachers or teaching staff, school entry flows and lack of facilities and infrastructure.

Keywords: Services, Education, People, Disabilities

\section{PENDAHULUAN}

Pendidikan merupakan suatu usaha yang dilakukan pemerintah dalam upaya mencapai tujuan nasional yaitu mencerdaskan kehidupan bangsa, oleh karenanya pemerintah menjamin hak warga negara untuk mendapatkan pendidikan. Hal tersebut tertera pada Undang Undang Nomor 20 Tahun 2003 tentang Sistem Pendidikan NasionalPasal 5 Ayat (1) yang menyatakan bahwa "Setiap warga negara mempunyai hak yang sama untuk memperoleh pendidikan yang bermutu". Pendidikan tidak hanya untuk golongan tertentu saja, melainkan untuk semua warga negara termasuk warga negara yang berkebutuhan khusus.

Berdasarkan data dari Badan Pusat Statistik (BPS) pada tahun 2017, "jumlah anak berkebutuhan khusus (ABK) di Indonesia mencapai angka 1,6 juta anak. Salah satu upaya yang dilakukan Kementerian Pendidikan dan Kebudayaan (Kemendikbud, 2017) untuk memberikan akses pendidikan kepada mereka adalah dengan membangun unit sekolah baru, yaitu Sekolah Luar Biasa (SLB), dan mendorong tumbuhnya Sekolah Inklusi di daerah-daerah.Dari 1,6 juta anak berkebutuhan khusus di Indonesia, baru 18 persen yang sudah mendapatkan layanan pendidikan inklusi. Untuk memberikan akses pendidikan kepada ABK yang tidak bersekolahdi SLB, Kemendikbud telah menjalankan program Sekolah Inklusi. Sekolah Inklusi adalah sekolah regular (non-SLB) yang juga melayani pendidikan untuk anak berkebutuhan khusus. Di sekolah reguler, anak-anak berkebutuhan khusus belajar bersama anak-anak reguler lainnya, dengan pendampingan guru khusus selama kegiatan belajar mengajar. Saat ini terdapat 32-ribu sekolah reguler yang menjadi Sekolah Inklusi di berbagai daerah. (Maulipaksi, 2017)

Oleh karena itu, selayaknya pendidikan bagi anak berkebutuhan khusus harus lebih diperhatikan karena tidak semua anak mampu belajar bersama dengan anak anak pada umumnya, disebabkan karena sangat sulit untuk dapat berkonsentrasi. Dalam kondisi seperti inilah dirasakan perlunya pelayanan yang 
memfokuskan kegiatan dalam membantu para peserta didik yang menderita gangguan disabilitas secara pribadi agar mereka dapat berhasil dalam proses pendidikannya. Fakta diatas menunjukkan bahwa pelayanan untuk siswa berkebutuhan khusus masih banyak membutuhkan perhatian, baik dari segi kurikulum, pendidikan, materi, dan evaluasinya. Pembelajaran harus disiapkan secara matang agar proses pembelajarnya bisa maksimal dan membuahkan hasil (Delphie, 2006).

Adapun di Sekolah Khusus Negeri 1 Kendari yang berada di Jalan Sao-Sao Kota Kendari merupakan salah satu sekolah yang di dirikan oleh Dinas Provinsi pada tahun 2014 yang dimana didalam sekolah tersebut memang terkhusus untuk anak berkebutuhan khusus yang juga ingin mendapatkan pendidikan yang layak seperti yang anak lainnya.. Sekolah ini mempunyai 103 siswa dan siswi yang dihuni dalam 11 ruangan dan memiliki keterbatasan baik secara fisik maupun mental, seperti tuna netra, tuna rungu, tuna granita, tuna daksa dan autis yang dipimpin oleh Kepala Sekolah dan dibantu dengan 12 guru dimana terdapat 3 guru tetap, 1 administrasi sekolah, dan 8 guru honor yang memiliki masing masing bidang dalam memberikan pelayanan terhadap anak penyandang disabilitas tersebut. Selain itu sumber dana yang digunakan untuk memenuhi kebutuhan sekolah berasal dari Dana APB Direktorat Pendidikan Khusus.

\section{METODE PENELITIAN}

Penelitian ini telah dilakukan di Sekolah Khusus Negeri 1 Kendari di Kelurahan Bende Kecamatan Kadia Kota Kendari. Penelitian ini dilakukan untuk lebih mendalami permasalahan yang ada pada Sekolah Khusus Negeri 1 Kendari karena terdapat anak penyandang disabilitas dan memiliki sebuah permasalahan, Dimulai pada bulan maret s/d juli 2020. Penelitian ini menggunakan jenis penelitian kualitatif disebut kualitatif karena sumber data utama yang digunakan dalam penelitian ini berupa kata-kata dan tindakan dari orang-orang yang diamati atau diwawancarai secara langsung dalam hal ini kepala sekolah, guru dan murid Sekolah Khusus Negeri 1 Kendari. Sedangkan bersifat deskriptif karena penelitian ini dimaksudkan untuk menggambarkan keadaan atau kondisi yang terjadi saat sekarang dan menyajikan apa adanya. Informan dalam penelitian ini berjumlah 10 yaang terdiri dari Kepala Sekolah Khusus Negeri 1 Kendari, 5 guru Sekolah Khusus Negeri 1 Kendari dan 3 Orang Tua Murid. Pengumpulan data adalah prosedur sistematis dan standar untuk memperoleh data yang diperlukan. Metode pengumpulan data yang digunakan dalam penelitian ini terdiri dari wawancara, observasi dan dokumentasi. Analisis data yang digunakan dalam penelitian ini adalah analisis deskriptif, artinya analisis data yang bukan menggunakan angka-angka melainkan dalam bentuk kata-kata, kalimat ataupun paragraf yang dinyatakan dalam bentuk deskriptif. Adapun langkah-langkah peneliti dalam menganalisis data sebagaimana dijelaskan oleh Sugiyono (2005) adalah : Reduksi data, penyajian data, dan penarikan kesimpulan.

\section{HASIL DAN PEMBAHASAN}

Anak berkebutuhan khusus atau anak penyandang disabilitas adalah anak dengan karakteristik khusus yang berbeda dengan anak pada umumnya. Karena karakteristik dan hambatan yang dimiliki, anak berkebutuhan khusus memerlukan bentuk pelayanan pendidikan khusus yang disesuaikan dengan kemampuan dan potensi mereka. Oleh karena itu, di dirikanlah sebuah sekolah khusus negeri 1 kendari dengan tujuan agar anak anak berkebutuhan khusus yang memiliki 
kekurangan mereka juga bisa menutut ilmu serta mengembangkan potensi yang mereka miliki sama seperti anak anak umum lainnya.Sekolah Khusus Negeri 1 Kendari yang terletak pada poros Jl. Sao Sao Kelurahan Bende Kecamatan Kadia Kota Kendari. Sekolah Khusus Negeri 1 Kendari sebelah utara berbatasan dengan Kantor Pusat Layanan Usaha Terpadu Sulawesi Tenggara, sebelah selatan berbatasan Global Islamic School Lazuardi Ibnu Sina Pra-TK, TK, \& SD, dan sebelah timur berada tepat depan Taman Budaya yang merupakan Jalan Poros Sao-Sao, Kota Kendari. Dan luas wilayah sekolah tersebut $720 \mathrm{M}^{2}$.

Sekolah Khusus Negeri 1 Kendari tersebut merupakan salah satu Sekolah yang berdiri tahun 2014 tepatnya 22 Desember dan untuk proses kegiatan belajar mengajar (KBM) itu sendiri baru mulai beroperasi awal 2015. Yang didirikan oleh Dinas Provinsi dan APB Direktorat Pendidikan. Sekolah ini didirikan agar anak penyandang disabilitas yang mengalami kekurangan secara fisik ataupun mental bukan berarti mereka tidak dapat mendapatkan pendidikan layaknya anak normal lainnya.

\section{Pelayanan Pendidikan Bagi Anak Penyandang Disablitas Di Sekolah Khusus Negeri 1 Kendari}

Sekolah Khusus Negeri 1 Kendari berjumlah 103 siswa dan siswi dari jenjang SD sebanyak 69 siswa, SMP sebanyak 21 siswa, dan SMA sebanyak 13 siswa. Yang terdiri dari berbagai macam penyandang disabilitas atau ketunaan di antaranya tuna nerta yang berjumalah 6 orang, tuna rungu yang berjumalah 8 orang, tuna daksa yang berjumlah 3 orang, tuna grahita yang berjumlah 64 orang dan tuna laras yang berjumlah 22 orang sehingga totalnya berjumlahjumlah secara keseluruhan 103 siswa. Dalam memberikan pelayanan untuk menangani anak berkebutuhan khusus juga dibimbing oleh masing masing guru dan menggunakan program serta fasilitas yang sesuai dengan kebutuhan anak anak tersebut dengan menggunakan cara pengajaran satu per satu agar setiap siswa dapat memahami apa yang telah diajarkan disekolah.

Dalam memberikan pelayanan kepada anak penyandang disabilitas tentunya berbeda dengan anak umum lainnya atau harus sesuai dengan kebutuhan anak tersebut dimana dalam memberikan pelajaran maupun dalam memberikan fasilitas sehingga harus mempunyai suatu strategi atau program khusus. Maka dalam strategi pembelajaran pada anak anak berkebutuhan khusus sedikit berbeda dengan anak pada umumnya. Anak yang berkebutuhan khusus dalam satu ruangan makasimal berjumlah 6 orang tidak boleh lebih namun karna kurangnya tenaga pendidik maka satu kelas ada yang berjumlah 9 dan 10 .

Strategi pengajaran terbagi atas tiga macam yaitu pendekatan secara satu per satu (individual) dan pendekatan secara berkelompok (individualisme) dengan mengajar penuh kasih sayang, tidak kasar (lemah lembut) dan yang terpenting tentunya kesabaran dalam mengajar. Peran guru dalam hal ini harus disesuaikan kemampuan siswa.

Untuk anak tuna grahita pengajarannya secara individualisme, tuna netra dan tuna rungu menggunakan metode pengajaran individual karna mereka mempunyai IQ normal namun tidak bisa melihat dan mendengar, anak autis menggunakan metode individualisme dan strategi untuk pengajaran anak berkebutuhan khusus semuanya menggukanan strategi pendekatan secara kasih sayang dan cara pembelajarannya terus di ulang-ulang sampai bisa dan tidak mengejar kurikulum tetapi menyesuaikan dengan kemampuan siswa namun tidak lari dari kurikulum. 
untuk kurikulum yang di terapkan di Sekolah Khusus Negeri 1 kendari yaitu kurikulum 2013, hanya saja di sekolah yang berkebutuhan khusus ada tambahan program yaitu program khusus. Untuk anak yang berkebutuhan khusus tuna netra program khususnya yaitu OM (Orientasi Mobilitas) yaitu pengenalan lingkungan adapun proses pembelajaran anak tuna netra yaitu menggunakan huruf braille, riglet, menggunakan huruf timbul. Tuna rungu yaitu anak yang tidak bisa bicara dan mendengar adapun program khususnya yaitu menggunakan bahasa isyarat, kemudian anak graditha yaitu anak yang mempunyai IQ rendah sehingga dalam segala hal mereka mengalami hambatan baik didikannya, perilakunya, maupun sosialisasinya dengan masyarakat, program khusus anak tuna graditha yaitu $3 \mathrm{M}$ (menolong diri sendiri, Merawat diri sendiri, Mengurus diri sendiri) agar mereka bisa mandiri. Tuna daksa yaitu anak yang mempunyai kelainan fisik atau cacat, program khususnya yaitu terapi misalnya berlatih memakai baju tanpa tangan. Kemudian anak tuna laras yaitu anak yang mempunyai kelainan emosi dan perilaku, program khususnya sama dengan anak tuna daksa yaitu terapi namun anak autis memiliki macam 2 terapi yaitu terapi perilaku dan terapi emosi.

\section{Tuna Netra}

Tuna Netra artinya gangguaan pada penglihatan. Sejalan dengan makna tersebut, istilah ini dipakai untuk mereka yang mengalami gangguan penglihatan yang mengakibatkan fungsi penglihatan tidak dapat dilakukan. Oleh karena gangguan tersebut, penyandang tuna netra menunjukkan perbedaan yang signifikan dengan mereka yang penglihatannya berfungsi secara normal. Sehubungan dengan itu, anak tuna netra mempunyai kebutuhan khusus yang menuntut adanya pelayanan khusus sehingga potensi yang dimiliki oleh para tuna netra dapat berkembang secara optimal. Anak tuna netra membutuhkan latihan khusus yang meliputi, latihan membaca dan menulis huruf braille, penggunaan tongkat, serta orientasi dan mobilitas.

khusus mengajar siswa tuna netra menggunakan alat khusus yang dinamakan rikret atau huruf dan angka timbul serta disediakan juga tongkat khusus yang memang digunakan hanya untuk kepada murid yang sangat membutuhkan. Sedangkan dalam memberikan program khusus di sekolah diterapkan metode orientasi mobilitas agar mereka dapat bergerak sesuai dengan tujuan mereka contohnya dapat mengetahui letak letak ruangan yang terdapat di lingkungan sekolah. Dalam proses belajar mengajar peserta didik dibimbing dengan cara individu atau dibimbing satu persatu murid hingga selesai agar guru nya bisa memahami sampai mana kemampuan muridnya tersebut. Maka disini guru harus mempunyai kesabaran serta ketelatenan dalam menberikan ilmu agar apa yang sampaikan dapat diterima dengan baik.

\section{Tuna Rungu}

Istilah tuna rungu digunakan bagi mereka yang mengalami gangguan pendengaran, mulai dari yang ringan sampai dengan yang berat. Gangguan ini dapat terjadi sejak lahir ( merupakan bawaan ), dapat juga terjadi setelah kelahiran. Istilah lain yang sering digunakan untuk menggambarkan anak yang mengalami gangguan pendengaran adalah anak tuli. Namun, sebenarnya istilah anak tuli ini hanya merupakan salah satu klasifikasi dari gangguan pendengaran. Oleh karena kondisi khusus ini, anak tuna rungu memerlukan bantuan khusus, baik dalam kehidupan sehari-hari maupun dalam pendidikan.

khusus tuna runggu diatas dengan melakukan pembinaan persepsi gerak dan irama menggunakan bahasa isyarat serta dengan selalu mengasah sisa sisa 
pendengaran siswa mengurangi kekurangan yang dimiliki atau melatih kemampuan yang masih adawalaupun hanya semampu mereka dengan tujuan untuk mengoptimalkan sisa-sisa pendengaran anak tuna rungu agar mereka mampu mengetahui setiap bunyi yang terjadi baik di dalam kelas maupun dilingkungan sekolah ketika sedang beraktivitas diluar kelas.

\section{Tuna Grahita}

Tuna grahita atau sering dikenal dengan cacat mental adalah kemampuan mental yang berada di bawah normal. Anak yang ber IQ 55 - 70 berbeda dengan yang ber IQ $35-55$. Dalam sebaran IQ tersebut juga berbeda dalam layanan masingmasing. Layanan pendidikan khusus bagi anak tuna grahita meliputi terapi bermain dan latihan mengurus diri sendiri. Pendekatan pembelajaran dilakukan secara individual. Tujuan utama layanan pendidikan bagi anak tuna grahita adalah penguasaan kemampuan aktivitas kehidupan sehari-hari dalam mengelola diri sendiri. Untuk mencapai itu perlu pembelajaran mengurus diri sendiri dan pengembangan keterampilan sesuai dengan kemampuannnya. sekolah tersebut memiliki hambatan yaitu kurangnya tenaga kerja atau guru terkhusus untuk tuna grahita dikarenakan jumlah murid disekolah sangat banyak. Dalam proses mengajar guru khusus tuna grahita ini selain memberikan pelajaran umum tentunya juga memberikan program pelayanan yang khusus. Pelayanan khusus bagi mereka dengan latihan bina diri (menolong, merawat, dan mengurus diri sendiri) dan lain sebagainya. Bimbingan tersebut bertujan agar mereka dengan kekurangan itu tidak menjadi penghalang untuk mereka dapat mandiri. Proses pembelajaran untuk anak tunagrahita harus dilakukan secara intensif karena mereka mempunyai IQ yang minim atau dibawah rata rata dibandingkan anak normal lainnya.

\section{Tuna Daksa}

Tuna daksa berarti cacat fisik. Oleh karena kecacatan ini, anak tersebut tidak dapat menjalankan fungsi fisik atau tubuh secara normal. Layanan pendidikan khusus bagi anak tuna daksa adalah bina gerak. Untuk memberikan layanan bina gerak yang tepat diperlukan dukungan terapi, untuk memulihkan kondisi otot, sendi dan tulang anak yang mengakibatkan gangguan dalam melakukan aktivitas mobilisasi dengan tujuan untuk memperbaiki dan mengembangkan fungsi gerak pada anak. Namun sebelumnya dilakukan asessmen untuk melihat dan menyesuaikan apa yang kekurangan dan apa yang butuhkan.

khusus tuna daksa di Sekolah Khusus Negeri 1 Kendari bahwa anak tuna daksa terbagi dalam dua jenis yaitu hanya cacat fisik dan ada juga yang cacat fisik disertai dengan gangguan kecerdasan atau biasa disebut cacat ganda. Dalam proses belajar mengajar tentunya juga berbeda, misalnya dalam mengajar anak tuna daksa yang hanya cacat fisik saja, mereka memiliki kecerdasan seperti anak umum lainnya jadi tidak begitu sulit memberikan penjelasan. Sedangkan anak tuna daksa yang disertai gangguan keceradasan tentunya berbeda harus lebih sabar serta memahami murid ketika mereka memberikan materi. Tapi dalam memberikan pelayanan bagi tuna daksa keduanya tentunya yang utama memberikan terapi bina gerak agar dapat mengembangkan perkembangan fisik murid baik melalui aktifitas seperti olahraga yang terbatas dan tertentu yang dilakukan dapat memperbaiki kemampuan gerak anak.

\section{Tuna Laras}

Tuna laras adalah sebutan untuk orang yang mengalami hambatan dalam mengendalikan emosi dan kontrol sosial. Biasanya anak yang 
mengalaminya memilki ciri berani melanggar peraturan, mudah emosi dan suka melakukan tindakan agresif. Untuk kelainan perilaku, pendekatan pendidikan bagi anak tunalaras menggunakan pendekatan bimbingan dan terapi. Selain pendekatan terapi, dalam pembelajaran khusus untuk anak tuna laras adalah bina pribadi sosial anak. Mata pelajaran ini diarahkan untuk membina perilaku positif anak tuna laras dalam kaitannya dengan perilaku dirinya dan perilaku dalam berhubungan dengan orang lain.

anak tuna laras adalah anak yang mengalami hambatan dalam mengendalikan emosi ataupun perilaku menyimpang sehingga kurang dapat menyesuaikan diri dengan lingkungannya, baik didalam keluarga, sekolah maupun masyarakat. Hal ini kadang merugikan dirinya sendiiri bahkan dari segi pendidikannya. Pendidikan untuk anak tuna laras dirancang sedemikian rupa sehingga dapat menghilangkan peilaku menyimpang dan menciptakan perilaku posiitif yang dimiliki setiap anak. Pada proses bimbingan bina pribadi dan sosial, anak diberikan materi sesuai dengan yang mereka butuhkan agar mereka mampu bersosialisasi dan beraktivitas dengan baik tentang pentingnya hidup bermasyarakat dan mampu memecahkan masalah pribadi dan sosial yang dihadapinya. dengan kesabaran oleh guru dalam mengajar yang dikarenakan emosi dan perilaku anak tuna laras yang kurang terkendali.

Faktor-Faktor Yang Mendukung Dan Menghambat Dalam Memberikan Pelayanan Terhadap Anak Penyandang Disabilitas Di Sekolah Khusus Negeri 1 Kendari
1) Faktor Pendukung
a. Pemerintah
Peran pemerintah dalam memberikan dukungan kepada sekolah khusus negeri 1 kendari

cukup, karena tidak hanyak memberikan dukungan dalam bentuk moral tetapi juga dalam bentuk fisik seperti meberikan fasilitas sekolah yang sesuai dengan kebutuhan anak-anak penyandang disabilitas.

b. Keluarga

Peran orang tua sangat penting dalam meningkatkan anak mereka disekolah, peran keluarga adalah nomor satu karena aktivitas mereka sehari-hari dirumah sehingga orang tua juga bisa mengkontrol sampai mana perkembangan anak mereka dirumah setelah itu tenaga pendidik sebagai guru disekolah.bahwa sikap orang tualah yang sangat berpengaruh dalam tingkah laku anak karena perkembangan mereka dimulai di dalam satu keluarga sehingga orang tua sangat berperan penting. Orang tua yang penyayang, lemah lembut, dan adil maka akan menumbuhkan sikap sosial yang baik kepada anak-anak yang mereka didik serta anak tersebut menjadi semangat untuk bersekolah.

c. Guru/Pendidik

Guru atau pendidik adalah salah satu faktor pendidikan yang sangat penting karena pendidik merupakan orang yang bertanggung jawab dalam pembentukan kepribadian serta perkembangan kemampuan siswa siswi selama berada dilingkungan sekolah.

d. Lingkungan

Salah satu faktor pendukung yang turut memberikan pengaruh dalam terbentuknya sikap seseorang adalah lingkungan dimana orang tersebut berada. Lingkungan adalah faktor yang 
sangat penting dalam membentuk sikap dan perilaku yang baik setiap anak setelah lingkungan didalam keluarga, karena akan sangat mempengaruhi perkembangan seorang anak.

2) Faktor Penghambat

a. Kurangnya guru atau tenaga pengajar

Tenaga pendidik atau guru di sekolah tersebut hanya sepuluh orang. Tiga di antaranya merupakan guru pendidikan luar biasa atau guru spesialis, sisanya guru non pendidikan luar biasa. Ketujuh guru tersebut lulusan IPA, agama, Bahasa Indonesia, dan Matematika. Dalam kesehariannya mereka menjadi guru kelas. Guru khusus pada sekolah ini sangat dibutuhkan agar setiap guru bisa mengajar 4 sampai 5 siswa saja. Maka proses belajar mengajar dapat berlangsung dengan baik seperti apa yang diharapkan sekolah. Dalam hal ini guru khusus untuk anak tuna grahita sangat didominankan dalam penambahan jumlah tenaga pendidik karena dilihat dari jumlah siswa yang sang sangat banyak dari pada jumlah siswa tuna lainnya. Oleh karena itu, dibutuhkan guruguru yang memiliki latar belakang pendidikan luar biasa sebab di tangan merekalah potensi anakanak disabilitas digali karena anakanak disabilitas tidak hanya memiliki kekurangan, mereka juga dianugrahi kelebihan.

b. Keterlambatan masuk sekolah

Keterlamatan saat pendaftaran yang seharusnya anak didaftarkan pada saat umur 7 tahun tetapi kebanyakan didaftarkan diumur 10 tahun ke atas maka sekolah harus bisa menyesuaikan pembelajaran siswa yang baru masuk dengan lingkungan sekolah dan teman-temannya begitupun dengan siswa siswi yang lain agar mereka bisa mengenal antara satu sama lain. Keterlambatan orang tua dalam mendaftarkan anaknya juga dikarenakan belum siapnya anak tersebut untuk bersekolah, atapun dari orang tua yang belum tau sekolah ini.

c. Kurangnya sarana dan prasarana Pemerintah membiayai
sekolah dengan mengratiskan seluruh anak berkebutuhan khusus untuk bersekolah. Akan tetapi, untuk sarana dan prasarana yang ada disekolah masih membutuhkan fasilitas yang cukup, walaupun sebagian fasilitas telah tercukupi akan tetapi masih kurang walaupun sebagian sudah tercukupi. Karena sarana dan prasarana yang dibutuhkan dan harus disedikan juga mempengaruhi proses belajar mengajar berlajan dengan maksimal atau tidak.

\section{KESIMPULAN}

Berdasarkan hasil penelitian dan pembahasan yang telah diuraikan sebelumnya, maka dapat diambil kesimpulan bahwa layanan anak berkebutuhan khusus yang dilakukan di Sekolah Khusus Negeri 1 Kendari penyelenggara khusus di wilayah Kecamatan Kadia Kelurahan Bende Kota Kendari adalah sebagai berikut: 1) Dalam memberikan pelayanan kepada anak penyandang disabilitas tentunya berbeda dengan anak umum lainnya atau harus sesuai dengan kebutuhan anak tersebut dimana dalam memberikan pelajaran maupun dalam memberikan fasilitas sehingga harus mempunyai suatu strategi atau program khusus.2) Pelayanan pendidikan bagi anak berkebutuan khusus disekolah penyelenggara dilihat dari 
tenaga pendidik masih belum sepenuhnya efektif akan tetapi dengan adanya kegiatan seminar ataupun workshop pendidikan khusus maka guru guru dapat mengajar dengan semaksimal mungkin. Serta guru juga harus mempunyai karakter khusus dalam melangsungkan proses belajar mengajar diruangan agar dapat menciptakan suasana yang nyaman dikelas agar semua siswa siswi dapat menerima ilmu dengan baik. Dan dukungan dari keluarga dan lingkunga adalah nomor satu karena aktivitas mereka sehari-hari dirumah sehingga orang tua juga bisa mengkontrol sampai mana perkembangan anak dari sekolah. Dan peran pemerintah dalam memberikan dukungan kepada Sekolah Khusus Negri 1 Kendari dapat di acungi jempol karena tidak hanyak memberikan dukungan dalam bentuk moral tetapi juga dalam bentuk fisik seperti meberikan fasilitas sekolah yang sesuai dengan kebutuhan anak-anak penyandang disabilitas.

\section{DAFTAR PUSTAKA}

Badan pusat statistik (BPS) 2017, Anak Berkebutuhan Khusus Di Indonesia;

Budiyanto. (2012). Modul Pelatihan Pendidikan Inklusif. Jakarta: Kementerian Pendidiikan dan Kebudayaan, Direktorat Jenderal Pendidikan Dasar, Direktoral Pembinaan Pendidikan Khusus dan Layanan Khusus Pendidikan Dasar. https://www.kemdikbud.go.id/main/bl og/2017/02/sekolah-inklusi-dan pembangunan-slb-dukungpendidikan-inklus

Data Dari Sekolah Khusus Negeri 1 Kendari, 2014;

Delphie, Bandi. Pembelajaran Anak Berkebutuhan Khusus Dalam pendidikan Inklusi(Bandung:

PT. Refika Aditama,s 2006)
Maulipaksi, D. $(2017,2)$ Retrived 2 Rabu 2, 2009 From Kementrian Pendudukan Dan Kebudayaan.

Stubbs, Sue. Pendidikan Inklusif Ketika Hanya Ada Sedikit Sumber, 2002

Sugiyono. Metode Penelitian Kuantitatif, Kualitatif dan R\&D,(Bandung: Alfabeta, 2008)

Umbara, Citra. Undang-undangRepublik Indonesia Nomor 20 tahun 2003 tentang Sistem Pedidikan Nasional (Bandung:, 2006)

UU No 20 Tahun 2003 tentang Sistem Pendidikan NasionalPasal 5 Ayat (1).

Winarsih, M. (2017). Membaca Ideovisual Untuk Siswa Tunarungu. Perspektif Ilmu Pendidikan.

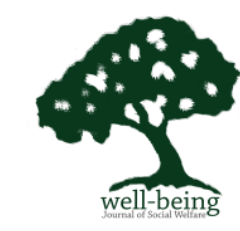

